\title{
FLORA MALESIANA PRECURSOR FOR THE TREATMENT OF MORACEAE 2: FICUS SUBGENUS PHARMACOSYCEA SECTION OREOSYCEA
}

\author{
C.C. BERG
}

The Norwegian Arboretum/Botanical Institute, University of Bergen,

N-5259 Hjellestad, Norway

\section{SUMMARY}

The position of Ficus subg. Pharmacosycea sect. Oreosycea and its subdivision are briefly discussed. A new subsection Glandulosae C.C. Berg is established. Five new species are described for the Malesian region: F. carinata, F. matanoensis, F. saruensis, F. sclerosycia, and $F$. subcaudata. Ficus pubinervis Blume and $F$. minor King are reduced to subspecies of $F$. nervosa Roth.

Key words: Moraceae, Ficus subg. Pharmacosycea sect. Oreosycea, Malesia.

\section{INTRODUCTION}

Corner (1958) included a number of Old World Ficus species in subgenus Pharmacosycea, initially comprising only Neotropical species (Miquel, 1848, 1867). In spite of indications from molecular studies (Herre et al., 1996; Weiblen, 2000) that the Palaeotropical and Neotropical species are very remotely related, morphological differences between these two groups of species are small and comparable with differences found at subsection level in other major subdivisions (subgenera) of Ficus and the differences found between Neotropical species of subg. Urostigma (Gasp.) Miq. (sect. Americana Miq.) and the group of Palaeotropical species belonging to sect. Urostigma and sect. Conosycea (Miq.) Corner. Both groups of species of subg. Urostigma and subg. Pharmacosycea have similar ranges of distribution: from the Pacific to West Africa and in tropical America.

Within the Palaeotropical sect. Oreosycea, two subsections can be distinguished, each with two subordinate groups of species (at the series level, but not treated as such).

\section{SUBDIVISIONS AND SPECIES}

Subg. Pharmacosycea

Sect. Pharmacosycea (Neotropics)

Sect. Oreosycea

Subsect. Glandulosae

Ficus nervosa-group

Ficus austrocaledonica-group

Subsect. Pedunculatae

Ficus albipila-group

Ficus vasculosa-group 
Ficus L. subg. Pharmacosycea (Miq.) Miq. sect. Oreosycea (Miq.) Miq. subsect. Glandulosae C.C. Berg, subsect. nov.

A subsect. Pedunculatis foliis infra nervorum lateralium basalium in axillis maculis ceraceis glandulosis differt. - Typus: Ficus nervosa Roth.

Indumentum often brownish. Leaves in spirals to distichous; lamina usually drying brownish; margin entire, also when juvenile; waxy glandular spots in the axils of basal (or second pair) of lateral veins; petioles about equal in length on the same twig; stipules often long. Fig receptacle often stipitate. Staminate flowers near the ostiole or scattered among the pistillate ones.

Distribution - From the Asian mainland to Taiwan, through the Malesian region to the Pacific, eastwards to New Caledonia, with centres in eastern Malesia and New Caledonia. Mostly lowland species of wet forest.

Morphology - The trees often show more or less clearly 'Terminalia-branching', i.e., intermittent sympodial growth, usually with the first internode(s) of the lateral branches rather short, the second (or third) long, and the subsequent ones becoming gradually shorter, so that the leaves become more or less clearly tufted at the end of the twigs (as in F. matanoensis).

Subdivision - Two groups of species can be distinguished:

1) Ficus nervosa-group (series Nervosae Corner, 1960: 407), comprising 19 species and ranging from Sri Lanka to Taiwan and to the Solomon Islands. The group comprises the Malesian species listed below and F. setulosa C.C. Berg endemic to the Solomon Islands (Berg, 2002).

2) Ficus austrocaledonica-group (series Austrocaledonicae Corner, 1960: 407). Twentyfive species are currently recognized (see Corner, 1965, 1970a, b; Berg, 2002): F. asperula Bureau, F. auriculigera Bureau, F. austrocaledonica Bureau, F. barraui Guillaumin, F. bubulia C.C. Berg, F. cataractum Bureau, F. crescentioides Bureau, F.dzumacensis Guillaumin, F. granatum G.Forst., F. habrophylla Seem., F. heteroselis Bureau, F. illiberalis Corner, F. leiocarpa Bureau, F. magwana C.C. Berg, F. maialis Bureau, F. mutabilis Bureau, F. nitidifolia Bureau, F. novae-georgiae Corner, F. otophora Corner \& Guillaumin, F. pancheriana Bureau, F. racemigera Bureau, F. smithii Baker, F. veillardiana Bureau, F. versicolor Bureau, and F. webbiana Miq. The majority are endemics to New Caledonia (see Corner, 1970a). In contrast to Corner's opinion (1960, 1967, 1970a), the group is also represented in the New Hebrides, Fiji, and the Solomon Islands, with a total of four species (Berg, 2002). This group differs from the F. nervosa-group, e.g., in the absence of long stipules, the pale colour of the dried laminas, and the occurrence of chartaceous laminas and subpachycladous (or in Corner's terminology pachycaul) growth forms.

Malesian species currently recognized in Ficus L. subg. Pharmacosycea (Miq.) Miq. sect. Oreosycea (Miq.) Miq. subsect. Glandulosae C.C. Berg are: 1) F. carinata C.C. Berg (see below); 2) F. edelfeltii King (incl. F. homodroma Corner (1970a), F. mesotes Corner (1970a); excl. F. edelfeltii var. bougainvillei Corner, see Berg, 2002); 3) F. gigantifolia Merr.; 4) F. gratiosa Corner; 5) F. hadroneura Diels; 6) F. hombroniana Corner (incl. F. madhucifolia Corner); 7) F. ihuensis Summerh.; 8) F. kjellbergii Corner; 9) F. magnoliifolia Blume; 10) F. matanoensis C.C. Berg (see below); 11) F. nervosa 
Roth subsp. pubinervis (Blume) C.C. Berg (see below); 12) F. pachysycia Corner; 13) F. polyantha Warb.; 14) F. pseudojaca Corner; 15) F. saruensis C.C. Berg (see below); 16) F. sclerosycia C.C. Berg (see below); 17) F. subcaudata C.C. Berg (see below); 18) F. subnervosa Corner; 19) F. subtrinervia Lauterb. \& K. Schum. (incl. F. pachystemon Warb.). - For other included synonyms and varieties see Corner's check-list (1965: 30-32).

Ficus L. subg. Pharmacosycea (Miq.) Miq. sect. Oreosycea (Miq.) Miq. subsect. Pedunculatae Sata (1944) 179. - Lectotype (Corner, 1960: 406): F. callosa Willd.

Indumentum whitish. Leaves in spirals; lamina often drying greenish; margin (often) lobate or dentate when juvenile; basal lateral veins hardly or not distinct; waxy glandular spots lacking; petioles varying in length on the same twig or not; stipules relatively short. Fig receptacle often with a very smooth surface. Staminate flowers ostiolar.

Distribution - The subsection comprises 9 species: 5 in Asia, 2 in Madagascar (F. ampana C.C. Berg and F. assimilis Baker), and 2 in Africa (F. dicranostyla Mildbr. and F. variifolia Warb.). In Asia, F. capillipes Gagnep. is confined to the Asian mainland, the others extend to Malesia (F. albipila even to Australia) or are confined to the Malesian region (F. bataanensis).

Subdivision - Two groups of species can be distinguished:

1) Ficus albipila-group (subser. Albipilae Corner, 1960: 406), comprising F. albipila and $F$. capillipes, the two continental African species, and $F$. assimilis, with subcoriaceous to coriaceous, hairy laminas, dull above when dry.

2) Ficus vasculosa-group (subser. Vasculosae Corner, 1960: 406), with F. bataanensis, F. callosa, F. vasculosa, and the Madagascan F. ampana with stiff, coriaceous, and glabrous laminas, when dry usually shining and with the venation rather conspicuous above.

Malesian species currently recognized in Ficus L. subg. Pharmacosycea (Miq.) Miq. sect. Oreosycea (Miq.) Miq. subsect. Pedunculatae Sata are: 20) F. albipila (Miq.) King; 21) F. bataanensis Merr.; 22) F. callosa Willd.: 23) F. vasculosa Miq. - For included synonymy and varieties see Corner's check-list (1965: 29-30).

\section{NEW SPECIES AND COMBINATIONS}

Ficus carinata C.C. Berg, spec. nov. - Fig. 1

Fico hombrianae similis, sed laminae latere inferiore indumento, stipulis brevibus carinatus gaudet. - Typus: Buwalda 4972 (holo L), Indonesia, Moluccas, Aru Islands, P. Wokam, Dosinamaloe, 16 May 1938.

Tree. Branchlets drying (dark) brown to blackish. Leafy twigs $1.5-3 \mathrm{~mm}$ thick, solid, \pm angular, brownish puberulous. Leaves in spirals; lamina elliptic to oblong to (sub)obovate, $4.5-11$ by $2.5-5.5 \mathrm{~cm}$, symmetric, coriaceous, apex (shortly and bluntly) acuminate, base obtuse to rounded, margin entire, \pm revolute; upper surface glabrous, dull when dry, lower surface (minutely) brownish puberulous, mainly on 


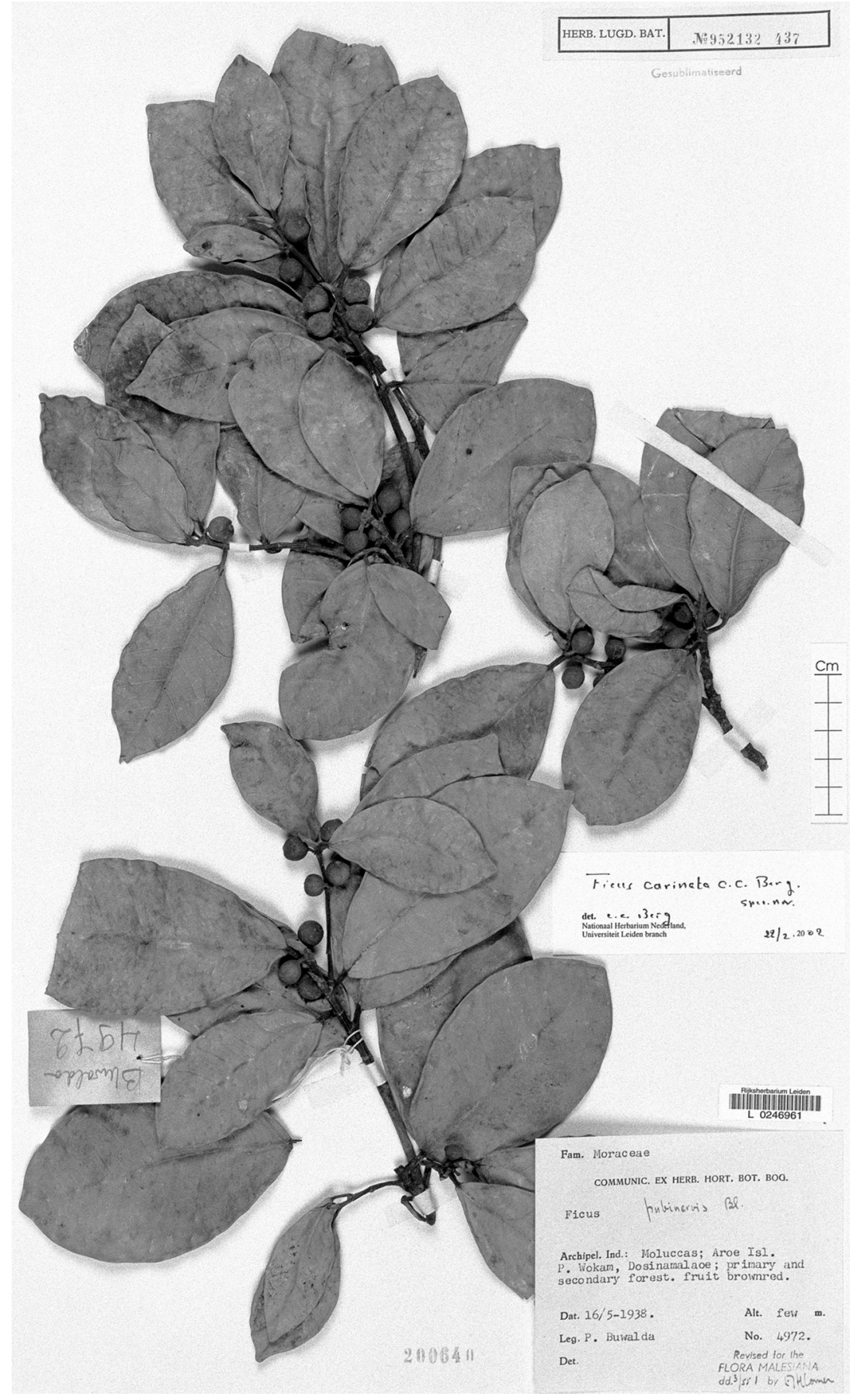

Fig. 1. Ficus carinata C.C. Berg. Indonesia, Moluccas, Aru Islands, P. Wokam, Dosinamaloe (Buwalda 4972, L). 
midrib and lateral veins, smooth; midrib almost flat above, lateral veins (6-) $8-12$ pairs, the basal pair slightly distinct, tertiary venation reticulate to partly parallel to the lateral veins, the smaller veins slightly prominent to flat beneath; waxy glands in the axils of the basal lateral veins; petiole $0.4-0.8 \mathrm{~cm}$ long, brownish puberulous, the epidermis flaking off; stipules c. $1 \mathrm{~cm}$ long, keel prominent, appressed-puberulous on the keel and ciliolate, caducous. Figs axillary, in pairs, sessile; basal bracts 3, verticillate, 1-1.5 mm long, persistent; receptacle subglobose, 0.7-1 cm diam. when dry, 0.2-0.5 cm long stipitate, sparsely glabrous, red-brown (?) at maturity, apex convex, ostiole c. $1 \mathrm{~mm}$ diam., slightly prominent; internal hairs absent. Staminate flowers ostiolar. Tepals (dark) red, glabrous. Stamen 1.

Distribution - The species is known only from the type locality.

Habitat - Forest, at low altitude.

Ficus matanoensis C.C. Berg, spec. nov. - Fig. 2

Fico carinatae similis, stipulis dense pubescentibus ecarinatis, ficis sessilibus differt. - Typus: De Vogel 6242 (holo L), Indonesia, Sulawesi, N-shore of Lake Matano, Bonemaitu, 420 m, 13 July 1979.

Tree up to $20 \mathrm{~m}$ tall. Branchlets drying (dark) brown. Leafy twigs $1.5-3 \mathrm{~mm}$ thick, solid, \pm angular, brown appressed-puberulous to subtomentose. Leaves in spirals; lamina oblong to elliptic or to lanceolate, $(3-) 5-18$ by (1-) $2.5-5.5 \mathrm{~cm}$, symmetric, coriaceous, apex (sub)acuminate to rounded, base obtuse to subattenuate, margin entire, \pm revolute to flat; upper surface sparsely appressed-puberulous to subtomentose, mainly on the midrib, glabrescent, \pm shining when dry, lower surface brown appressed-puberulous to subsericeous to subtomentose, mainly on the main veins, smooth; midrib almost flat to slightly impressed above, lateral veins $5-15$ pairs, \pm impressed above, loopconnected far from the margin, the basal pair \pm distinct, tertiary venation reticulate to partly parallel to the lateral veins, the smaller veins slightly prominent to flat beneath; waxy glands in the axils of the basal lateral veins; petiole (0.1-) $0.4-1 \mathrm{~cm}$ long, brown appressed-puberulous to subtomentose, the epidermis flaking off; stipules $0.8-1 \mathrm{~cm}$ long, brown appressed-puberulous to subsericeous, caducous. Figs axillary, in pairs or solitary, sessile; basal bracts 3, verticillate, 1-1.5 cm long, persistent; receptacle subglobose, when dry $0.7-1 \mathrm{~cm}$ diam., substipitate, (sparsely) brownish puberulous to subtomentose, red at maturity, apex convex, ostiole $1-1.5 \mathrm{~mm}$ diam., slightly sunken to flat and surrounded by a low rim or slightly prominent; internal hairs absent. Staminate flowers ostiolar to disperse. Tepals (dark) red, glabrous. Stamen 1.

Distribution - Malesia: Sulawesi.

Habitat - Forest, at low altitudes.

Notes -1 . This species resembles $F$. carinata from which it differs in the non-carinate and densely hairy stipules and sessile figs. Moreover, the lateral veins are more or less impressed.

2. The collection made from a shrub (De Vogel 6229) has lanceolate laminas, whereas the other is made from a tree and has oblong to elliptic ones. This suggests that the lanceolate lamina is (sub)juvenile trait as it is in F. subtrinervia.

3. The description is also based on De Vogel 6229 (L) and Widjaja 733 (L). 


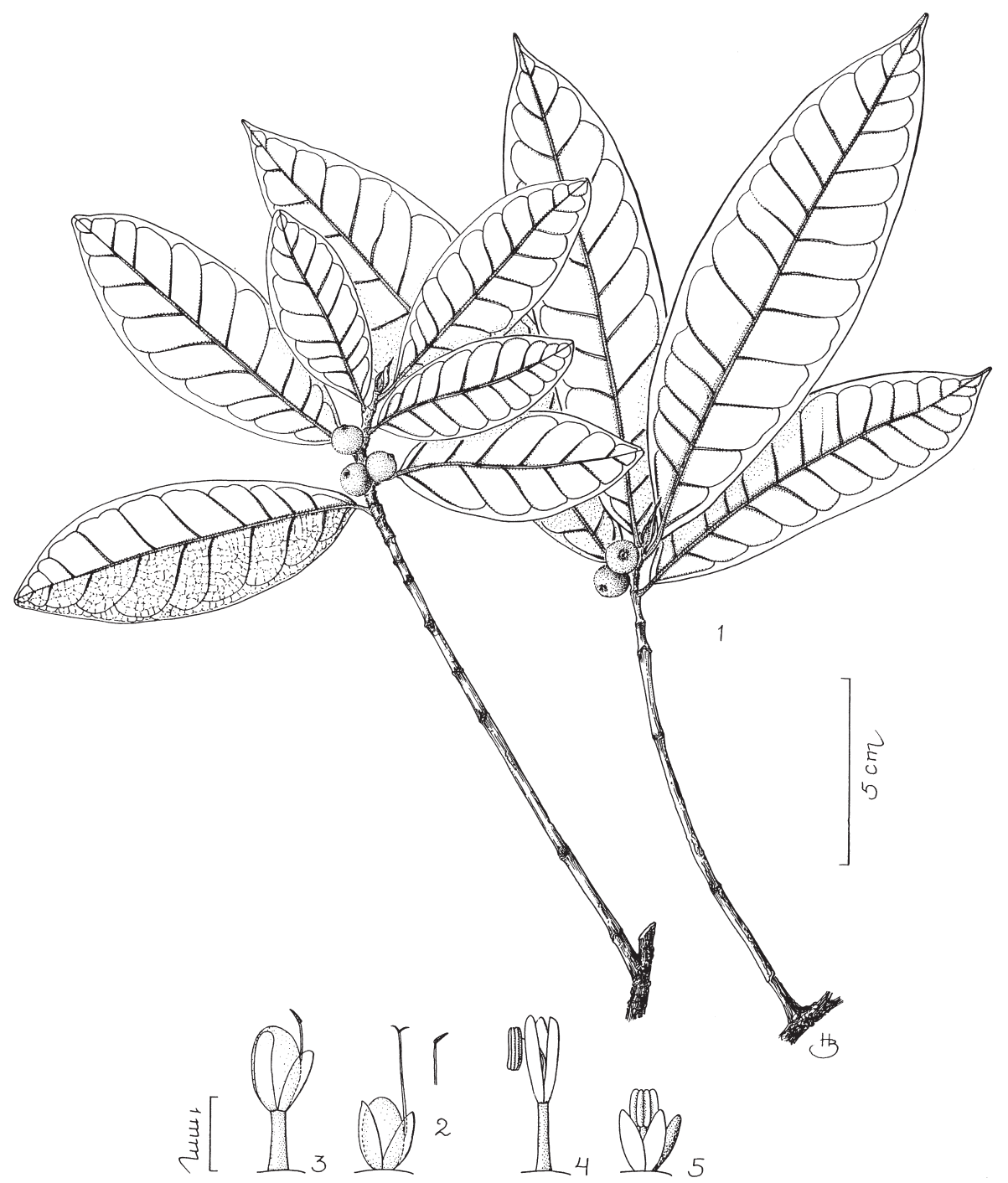

Fig. 2. Ficus matanoensis C.C. Berg. 1. Leafy twigs with figs, left (De Vogel 6242), right (De Vogel 6229); 2. long-styled pistillate flower, stigma; 3 . short-styled pistillate flower; 4. pedicellate staminate; 5. sessile staminate flower (De Vogel 6242).

Ficus saruensis C.C. Berg, spec.nov. - Fig. 3

Fico matanoense similis, stipulis longioribus, laminae costa supra prominenti differt. - Typus: Streimann et al. NGF 45010 (holo LAE; iso K, L, according to the labels also sent to A, BISH, BO, BRI, CANB, PHN, SING, SYD, and US), Papua New Guinea, Prov. Morobe, Subprov. Lae, 7 miles SE of Garaina, Saru River, c. 750 m, 21 July 1970.

Treelet up to $3 \mathrm{~m}$ tall. Branchlets drying (dark) brown. Leafy twigs 2-3 mm thick, solid, \pm angular, brown subtomentose. Leaves in spirals to subdistichous; lamina oblong to 


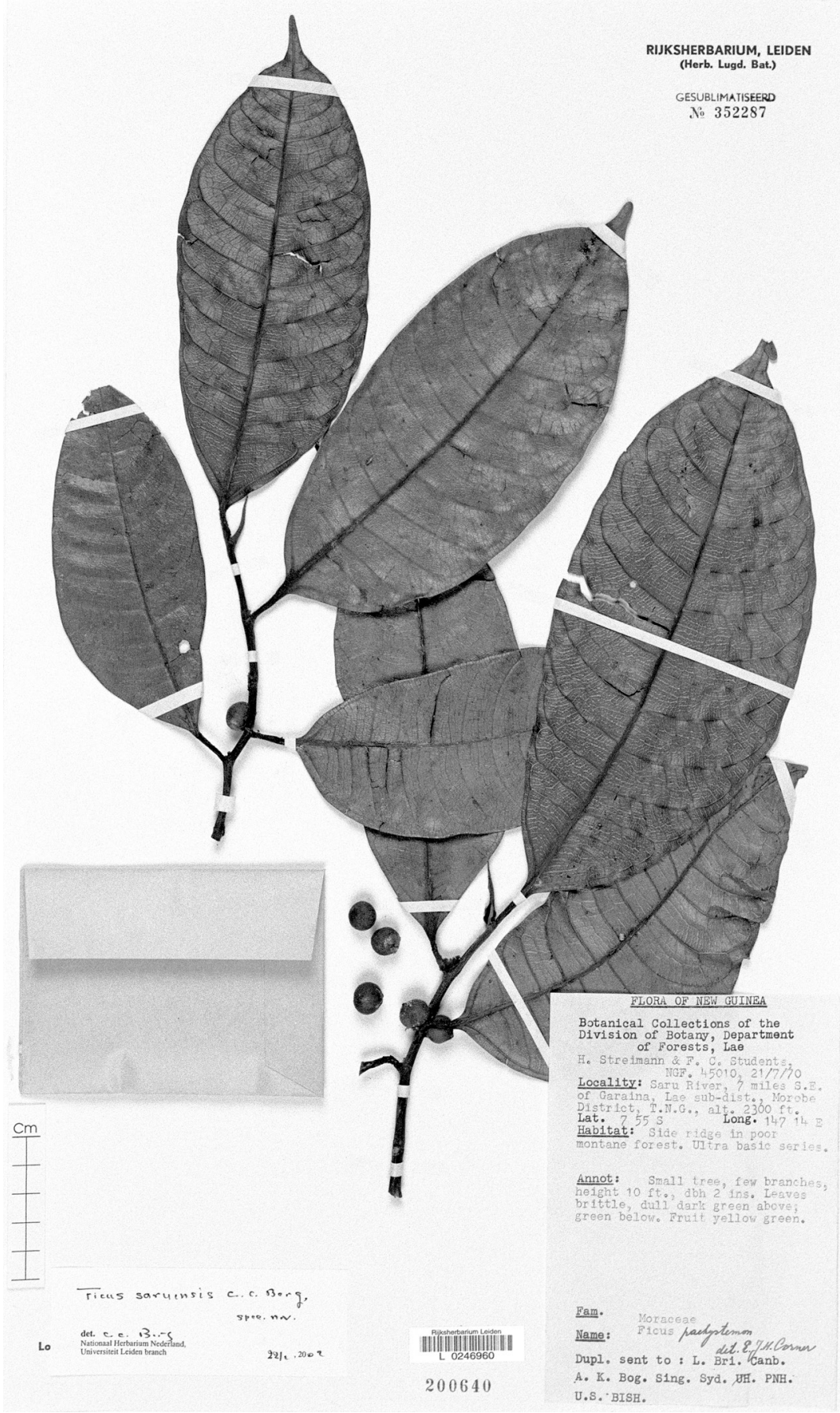

Fig. 3. Ficus saruensis C.C. Berg. Papua New Guinea, Prov. Morobe, Subprov. Lae, Saru River (Streimann et al. NGF 45010, L). 
lanceolate, $14-22$ by $4-8.5 \mathrm{~cm}$, symmetric, coriaceous, apex (sub)acuminate, base rounded to cuneate to subattenuate, margin entire, towards the base slightly revolute; upper surface (very) sparsely puberulous on the midrib, \pm shining when dry, lower surface subtomentose on the main veins, smooth; cystoliths only beneath; midrib slightly prominent to flat above, lateral veins $12-15$ pairs, slightly impressed to flat, the basal pair \pm distinct, tertiary venation reticulate to subscalariform, the smaller veins slightly prominent beneath; waxy glands in the axils of the basal lateral veins; petiole $(0.5-)$ $1-1.5 \mathrm{~cm}$ long, brownish subtomentose, the epidermis flaking off; stipules $2-3.5 \mathrm{~cm}$ long, densely brown appressed-puberulous to subglabrous, caducous. Figs axillary, in pairs or solitary, sessile; basal bracts 3, verticillate, 2-4 mm long, persistent; receptacle subglobose, $0.7-1.2 \mathrm{~cm}$ diam. when dry, non-stipitate, sparsely puberulous, greenish at maturity, apex convex, ostiole c. $1.5 \mathrm{~mm}$ diam., \pm prominent; internal hairs absent. Staminate flowers ostiolar. Tepals red, glabrous. Stamens (1 or) 2.

Distribution - Malesia: New Guinea (eastern).

Habitat - Forest, at altitudes up to c. $750 \mathrm{~m}$.

Note - The description is also based on Brass 28076 (L).

Ficus sclerosycia C.C. Berg, spec. nov. - Fig. 4 (7-11)

Fico pachysyciae similis, laminis et fici receptaculis minoribus differt. - Typus: Hartley TGH 13153 (holo L), Papua New Guinea, Prov. Eastern Highlands, c. 15 miles SW of Okapa, Wanatabi, c. 1650 m, 29 Sept. 1964.

Tree up to c. $30 \mathrm{~m}$ tall. Branchlets drying (dark) brown to blackish; scars of the petioles prominent. Leafy twigs $2.5-4 \mathrm{~mm}$ thick, solid, angular, sparsely and minutely appressed-puberulous. Leaves in spirals; lamina elliptic to oblong, $4.5-7$ by $2-4 \mathrm{~cm}$, symmetric, coriaceous, apex obtuse, base equilateral, obtuse to rounded, margin entire, revolute; upper surface glabrous, dull when dry, lower surface glabrous, smooth; midrib almost flat and the lateral and smaller veins slightly prominent and conspicuous above, lateral veins 7-9 pairs, the basal pair not or hardly distinct, tertiary venation reticulate to partly parallel to the lateral veins, the smaller veins almost flat beneath; waxy glands in the axils of the basal lateral veins; petiole $0.6-1 \mathrm{~cm}$ long, glabrous, the epidermis flaking off; stipules 1-1.5 cm long, densely brownish appressed-puberulous, caducous. Figs axillary, in pairs or solitary; peduncle $0.2-0.3 \mathrm{~cm}$ long; basal bracts ( 2 or) 3 , verticillate or scattered on the peduncle up to the base of the receptacle, 1-1.5 cm long, persistent; receptacle subglobose, 1.5-1.8 cm diam. when dry, (sub)glabrous, green (?) at maturity, apex convex to slightly umbonate, ostiole c. $2 \mathrm{~mm}$ diam., slightly prominent; wall 2-5 mm thick, in the middle thicker and dividing the cavity into two compartments; internal hairs absent. Staminate flowers disperse. Tepals (dark) red, glabrous. Stamens 2.

Distribution - Known only from the type locality.

Habitat - Forest, at c. $1650 \mathrm{~m}$.

Note - This species shows close affinities to F. pachysycia Corner, as in the shape and venation of the lamina and in the thick-walled fig receptacle, but both the lamina and the fig receptacle are so much smaller that it is not likely that the material described represents a small-leaved form of $F$. pachysycia. 


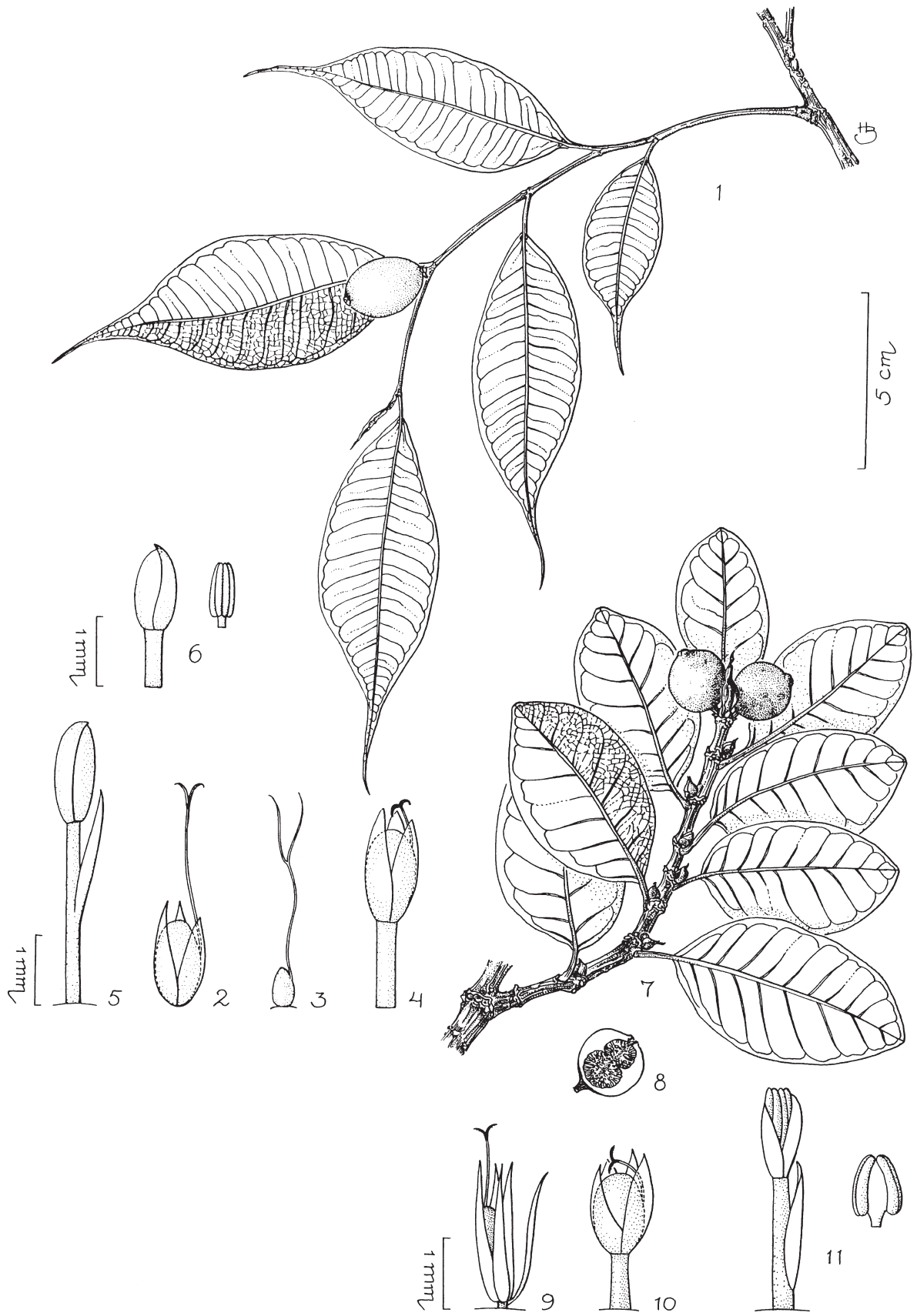

Fig. 4. 1-6: Ficus subcaudata C.C. Berg. 1. Leafy twig with fig; 2. long-styled pistillate flower; 3. pistil; 4. short-styled pistillate flower; 5 . short-styled pistillate flower with interfloral bract on the pedicel; 6. staminate flower and stamen (Ridsdale et al. NGF 33146). - 7-11: Ficus sclerosycia C.C. Berg. 7. Leafy twig with figs; 8. fig, interior; 9. long-styled pistillate flower; 10. short-styled pistillate flower; 11. staminate flower with interfloral bract on the pedicel and stamen (Hartley TGH 13153). 
Ficus subcaudata C.C. Berg, spec.nov. - Fig. 4 (1-6)

Laminae parvae asymmetricae apicis acumine longo distincta. - Typus: Ridsdale et al. NGF 33146 (holo LAE; iso BO n.v, L), Indonesia, Papua, Okwalimkan R., 4000 ft, 20 June 1967.

Tree up to $8 \mathrm{~m}$ tall. Branchlets drying (dark) brown, drooping. Leafy twigs 1-2 mm thick, solid, slightly angular to subterete, glabrous. Leaves in spirals to subdistichous; lamina elliptic to oblong, 4-13 by $1.5-5 \mathrm{~cm}, \pm$ asymmetric, coriaceous, apex subcaudate, base inequilateral to equilateral, cuneate to obtuse, margin entire, flat; upper surface glabrous, dull when dry, lower surface glabrous, smooth; midrib almost flat above, lateral veins 9-11 pairs, the basal pair slightly or not distinct, tertiary venation reticulate to partly parallel to the lateral veins, the smaller veins slightly prominent to flat beneath; waxy glands in the axils of the basal lateral veins; petiole $0.4-1.2 \mathrm{~cm}$ long, glabrous, the epidermis flaking off; stipules $1-1.5 \mathrm{~cm}$ long, glabrous, caducous. Figs axillary, solitary, sessile; basal bracts 3, verticillate, c. $1.5 \mathrm{~mm}$ long, persistent; receptacle subglobose, dry c. $1.5 \mathrm{~cm}$ diam. when dry, non-stipitate, glabrous, red at maturity, apex convex, ostiole $2-2.5 \mathrm{~mm}$ diam., slightly prominent; wall thick; internal hairs absent. Staminate flowers disperse. Tepals (dark) red, glabrous. Stamen 1.

Distribution - Malesia: New Guinea (western).

Habitat - Limestone cliffs, at altitudes of c. 1300-1400 m.

Notes -1 . This species is distinctive by its small, \pm asymmetric lamina with a long acumen, and probably also by the slender (usually?) drooping branches and the habitat (limestone rock).

2. The description is also based on Soegeng Reksodihardjo 611 (L; according to the label sent from BO to A, BM, BRI, BZF, Canberra, G, Hawaii, Ithaca, KEP, LAE, P, PNH, SAN, SING, Sydney, NY, US).

Ficus nervosa Roth in Roem. \& Schult. (1817) 513; Roth (1821) 388; Corner (1965) 31. - Type: Heyne s.n. (holo B), 'India orientalis'.

Three allopatric subspecies can be recognized and distinguished on the basis of quantitive differences: subsp. nervosa (ranging from India through Myanmar, Indochina, and S China to Taiwan) and with stipules shorter and figs smaller than in the Malesian subsp. pubinervis, and subsp. minor (King) C.C. Berg (confined to Sri Lanka and the adjacent part of India) with leaves smaller than in subsp. nervosa and the Malesian subsp. pubinervis. The pollinators of subsp. pubinervis and subsp. nervosa belong to different species of Dolichoris. On the other hand, subsp. nervosa and F. magnoliifolia Blume have pollinators distinct only at the subspecies level (Wiebes, 1994).

Ficus nervosa Roth subsp. minor (King) C.C. Berg, stat. nov. - Basionym: Ficus nervosa Roth var. minor King (1887) 53, t. 65B. - Lectotype (here designated): Thwaites 2219, Sri Lanka (holo CAL, sheet 425501; iso CAL), Ceylon.

Ficus nervosa Roth subsp. pubinervis (Blume) C.C. Berg, stat. \& comb. nov. - Basionym: Ficus pubinervis Blume (1825) 452. - Type: Indonesia, Java, without locality, Anonymus s.n. in herb. Blume (holo L). 


\section{KEY TO THE MALESIAN SPECIES OF SECTION OREOSYCEA}

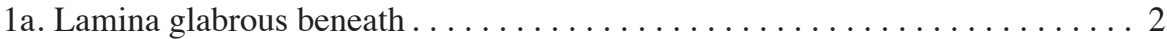

b. Lamina hairy beneath, at least sparsely so on the midrib . . . . . . . . 18

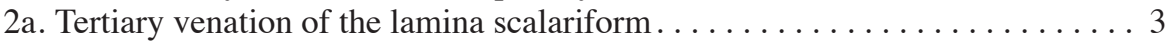

b. Tertiary venation of the lamina reticulate to subscalariform (with one or few transverse veins in the intercostal area) to partly or largely parallel to the lateral

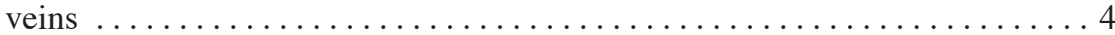

3a. Lamina scabridulous beneath, greenish and shining above when dry; figs pedunculate. - Malay Peninsula, Sumatra, Java, Borneo, Philippines, Sulawesi, Lesser

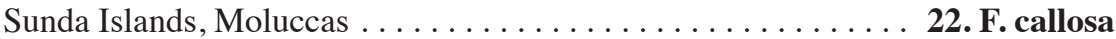

b. Lamina smooth beneath, dull and brownish above when dry; figs sessile. - Philippines $\ldots \ldots \ldots \ldots \ldots \ldots \ldots \ldots \ldots \ldots \ldots \ldots \ldots \ldots \ldots \ldots \ldots \ldots$ 3. F. gigantifolia

4a. Tertiary venation largely parallel to the lateral veins (with 1-3 secondary lateral veins between the primary ones). - New Guinea (incl. Admiralty Islands) . . . .

19. F. subtrinervia

b. Tertiary venation reticulate to subscalariform or to partly parallel to the lateral

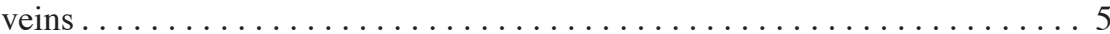

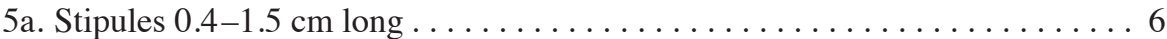

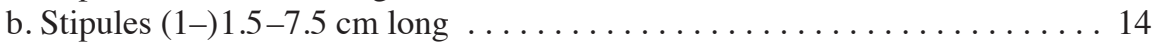

6a. Waxy glands absent; lamina (usually) drying greenish and shining above . . . 7

b. Waxy glands present in the axils of the basal lateral or the second pair of lateral veins; lamina drying brownish and dull above. - Sulawesi, Moluccas, and/or New Guinea . . . . . . . . . . . . . . . . . . . . . . . . . . 8

7a. Leafy twig and stipules glabrous; petiole $0.5-1 \mathrm{~mm}$ thick; fig receptacle $0.5-1 \mathrm{~cm}$ diam. when dry. - Malay Peninsula, Sumatra, Java, Borneo. . 23. F. vasculosa

b. Leafy twigs and stipules minutely puberulous; petiole 1-1.5 mm thick. - Philip-

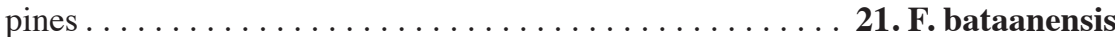

8a. Waxy glands in the axils of the second pair of lateral veins. - Sulawesi. . . . .

8. F. kjellbergii

b. Waxy glands in the axils of the basal lateral veins. . . . . . . . . . . . . 9

9a. Basal lateral veins clearly different from the other lateral veins, departing at a more acute angle. - Sulawesi, Moluccas, New Guinea . . . 6. F. hombroniana

b. Basal lateral veins not or hardly different from the other lateral veins. - New Guinea ................................ 10

10a. Apex of the lamina subcaudate; lamina often \pm asymmetric . 17. F. subcaudata

b. Apex of the lamina shortly acuminate to obtuse; lamina (almost) symmetric. 11

11a. Stipules brownish appressed-puberulous to subsericeous . . . . . . . . 12

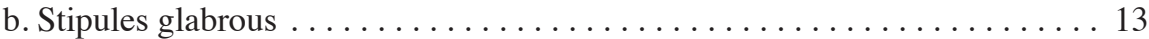

12a. Lateral veins (8-) 10-14 pairs; lamina usually longer than $10 \mathrm{~cm} \mathbf{2}$. F. edelfeltii

b. Lateral veins 7-9 pairs; lamina shorter than $10 \mathrm{~cm}$. . . . . 16. F. sclerosycia

13a. Petiole (0.5-) 1-2.5 cm long; stipules (0.5-) 1-2.8 cm long; fig receptacle (0.7-)

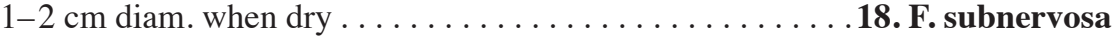

b. Petiole $0.4-1(-1.3) \mathrm{cm}$ long; stipules $0.5-1.2 \mathrm{~cm}$ long; fig receptacle $0.4-0.5 \mathrm{~cm}$ diam. when dry $\ldots \ldots \ldots \ldots \ldots \ldots \ldots \ldots \ldots \ldots \ldots \ldots \ldots \ldots \ldots$. F. ihuensis

14a. Lateral veins of the lamina $(8-) 10-17$ pairs . . . . . . . . . . . . 15

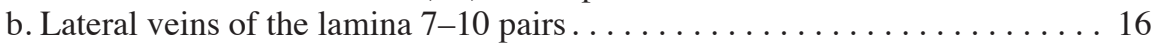


15a. Stipules usually hairy; leafy twigs \pm angular; epidermis of the petiole flaking off; figs usually subsessile and the receptacle hairy. - New Guinea . 2. F. edelfeltii

b. Stipules glabrous; leafy twigs terete to \pm compressed; epidermis of the petiole persistent; figs distinctly pedunculate and the receptacle glabrous. - Philippines, Moluccas, New Guinea . . . . . . . . . . . . . . . . . 13. F. polyantha

16a. Basal lateral veins clearly different from the other lateral veins, departing at a more acute angle; figs sessile. - Sulawesi, Moluccas, New Guinea . . . . . . . . .

6. F. hombroniana

b. Basal lateral veins not or hardly different from the other lateral veins; figs pedunculate. - New Guinea. . . . . . . . . . . . . . . . . . . . . . . . . . 17

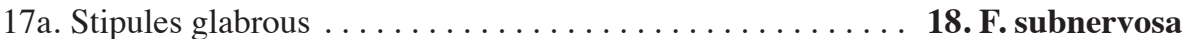

b. Stipules hairy $\ldots \ldots \ldots \ldots \ldots \ldots \ldots \ldots \ldots \ldots \ldots \ldots \ldots \ldots$ 12. F. pachysycia

18a. Tertiary venation parallel to the lateral veins (with 1-3 secondary lateral veins between the primary ones). - New Guinea (incl. Admiralty Islands) . . . . . . . . .

19. F. subtrinervia

b. Tertiary venation of the lamina scalariform, reticulate to subscalariform (with one or few transverse veins in the intercostal area) or to partly parallel to the lateral veins . . . . . . . . . . . . . . . . . . . . . . . 19

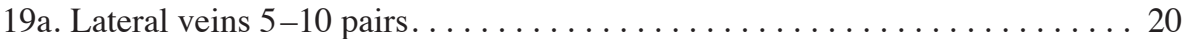

b. Lateral veins $(6-) 10-22$ pairs . . . . . . . . . . . . . . . 22

20a. Figs pedunculate, the receptacle (0.7-) 1-1.5 cm diam. when dry. - Sumatra, Java, Borneo, Philippines, Lesser Sunda Islands, Moluccas . .

11. F. nervosa subsp. pubinervis

b. Figs sessile, the receptacle $0.7-1 \mathrm{~cm}$ diam. . . . . . . . . . . . 21

21a. Lateral veins of the lamina impressed above; fig receptacle non-stipitate. -

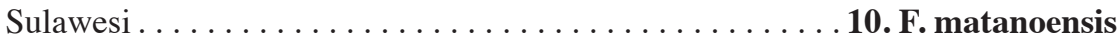

b. Midrib and lateral veins of the lamina (almost) flat above; fig receptacle stipi-

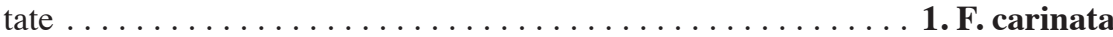

22a. Lateral veins of the lamina $(15-) 18-22$ pairs . . . . . . . . . . . . 23

b. Lateral veins of the lamina $(6-) 10-17$ pairs . . . . . . . . . . . . 24

23a. Stipules 1-3 cm long; fig receptacle sparsely whitish puberulous. - Malay Peninsula, Sumatra, Java, Borneo, Philippines, Sulawesi, Lesser Sunda Islands

9. F. magnoliifolia

b. Stipules (1.5-)2-5.5 cm long; fig receptacle densely brown puberulous. - New Guinea ........................ F. hadroneura

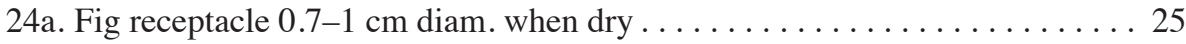

b. Fig receptacle $1-3.5 \mathrm{~cm}$ diam. when dry. . . . . . . . . . . . 26

25a. Stipules $0.8-1 \mathrm{~cm}$ long; petiole $0.4-1 \mathrm{~cm}$ long; lateral veins of the lamina impres-

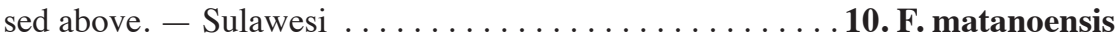

b. Stipules $2-3.5 \mathrm{~cm}$ long; petiole $1-1.5 \mathrm{~cm}$ long; lateral veins of the lamina slightly

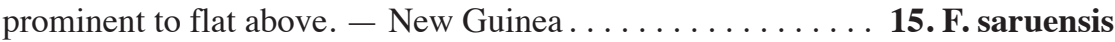

26a. Tertiary venation of the lamina scalariform . . . . . . . . . . . 27

b. Tertiary venation of the lamina reticulate to subscalariform (with one or few transverse veins in the intercostal area) or to partly parallel to the lateral veins . . 28

27a. Indumentum brown(ish); petioles of about similar length on the same twig; waxy glands in the axils of the basal lateral veins. - New Guinea .14. F. pseudojaca 
b. Indumentum white; petioles usually varying in length on the same twig; waxy glands absent. - Malay Peninsula, Sumatra, Java, Lesser Sunda Islands, New

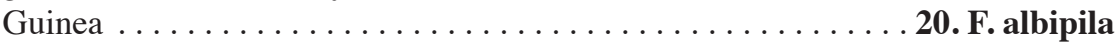

28a. Leafy twigs densely brown hairy; lamina \pm shining above when dry . . . . . 29

b. Leafy twigs sparsely and minutely whitish appressed-puberulous to glabrous;

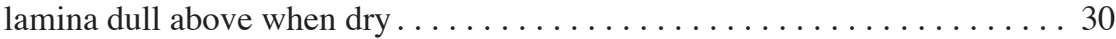

29a. Figs $0.2-0.8 \mathrm{~cm}$ long pedunculate. - Sulawesi . . . . . . . 4. F. gratiosa

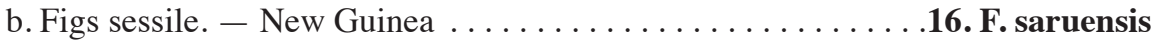

30a. Stipules $2-7 \mathrm{~cm}$ long; tertiary venation of the lamina reticulate to partly parallel to the lateral veins; fig receptacle $1-1.4 \mathrm{~cm}$ diam. when dry. - Sulawesi, Moluccas, New Guinea . . . . . . . . . . . . . . . hombroniana

b. Stipules $(0.5-) 1-2(-3) \mathrm{cm}$ long; tertiary venation of the lamina reticulate to subscalariform; fig receptacle (1-) $1.5-3.5 \mathrm{~cm}$ diam. when dry . . 2. F. edelfeltii

\section{ACKNOWLEDGEMENTS}

The Flora Malesiana Foundation supports the preparation of the treatment of Moraceae for Flora Malesiana. Dr. J.F. Veldkamp (Leiden) translated the diagnoses into Latin. Hendrieke Berg (Voss, Norway) prepared the drawings.

\section{REFERENCES}

Berg, C.C. 2002. Ficus subgenus Pharmacosycea section Oreosycea (Moraceae) in the Solomon Islands, Fiji, and the New Hebrides. Blumea 47: 299-314.

Blume, C.K. 1825. Bijdrage tot de flora van Nederlandsch Indië. Lands Drukkerij, Batavia.

Corner, E.J.H. 1958. An introduction to the distribution of Ficus. Reinwardtia 4, 3: 15-45.

Corner, E.J.H. 1960. Taxonomic notes on Ficus Linn., Asia and Australasia. II. Subgen. Pharmacosycea Miq. Gard. Bull. Singapore 17: 405-415.

Corner, E.J.H. 1965. Check-list of Ficus in Asia and Australasia with keys to identification. Gard. Bull. Singapore 21: 1-186.

Corner, E.J.H. 1967. Ficus in the Solomon Islands and its bearing on the Post-Jurassic history of Melanesia. Philos. Trans., Ser. B, 253: 23-159.

Corner, E.J.H. 1970a. Ficus subg. Pharmacosycea with reference to the species of New Caledonia. Philos. Trans., Ser. B, 259: 383-433.

Corner, E.J.H. 1970b. New species of Streblus and Ficus (Moraceae). Blumea 18: 393-411.

Herre, E.A., C.A. Machado, E. Bermingham, J.D. Nason, D.M. Windsor, S.S. McCafferty, W. van Houten \& K. Bachmann. 1996. Molecular phylogenies of figs and their pollinator wasps. J. Biogeogr. 23: 521-530.

King, G. 1887. The species of Ficus of the Indo-Malayan and Chinese countries. Ann. Roy. Bot. Gard. (Calcutta) 1, 1: 1-66, t. 1-87.

Miquel, F.A.W. 1848. Prodromus monographiae Ficuum. II. Pharmacosycea. London J. Bot. 7: 64-72.

Miquel, F.A.W. 1867. Annotationes de Ficus specibus. Ann. Mus. Bot. Lugd.-Bat. 3: 260-300.

Roemer, J.J. \& J.A. Schultes. 1817. Systema Vegetabilium 1. Gottae, Stuttgart.

Roth, A.W. 1821. Novae Plantarum Species. Vogleri, Halberstadt.

Sata, T. 1944. A monographic study of the genus Ficus from the point of view of economic botany. Contr. Hort. Inst. Taihoku Imp. Univ. 32: 1-405, 1-54.

Weiblen, G.D. 2000. Phylogenetic relationships of functionally dioecious Ficus (Moraceae) based on ribosomal DNA sequences and morphology. Amer. J. Bot. 87: 1342-1357.

Wiebes, J.T. 1994. The Indo-Australian Agaoninae (pollinators of figs). Verh. Kon. Ned. Akad. Wet., afd. Natk., 2de reeks, 92: 1-208. 